\title{
Health Survey of the Dairy Farmers of Bekkai Area in Hokkaido, Japan, With Special Reference to the Influence on the Farmers' Health of the Mechanization of Dairy Farm- ing *
}

Keizo Fujii, M. D., Yoshinori Iriuda, M. D.,

Kazuhiko Masuda, M. D. and Hiroko Tanaka**

Hokkaido is the northernmost big island in Japan. Bekkai Town is located in the midst of the great plains which are spread over the far northeastern part of Hokkaido. Bekkai area is known as the largest dairy farming area in Japan, where one thousand six hundreds and seven farmers are carrying on dairy farming. The pasture of Bekkai covers an area of one thousand three hundreds and thirty square kilometers. This area is cold and short of sunshine and the nature of the soil is not good for the farm crop.

The scale of dairy faming in this area had been relatively small until ten years ago, but for the present, each dairy farmer breeds milking cows ranging from ten to two hundreds with an average of forty five milking cows. Each dairy farmer owns the pasture of forty hectares in an average.

The Japanese Government has been planning to change this area into a model of the modern dairy farming place in Japan. Various Kinds ofagricultural machines and implements have been introduced, but the farmers must purchase them by the loaned money. Two big milk plants are taking care of all the milk produced in this area. Thus, the farmers in this area are fully controlled by Government and the milkplants.

Table 1 shows the state of population and area assigned to one doctor.

As indicated in this table, the population of this area is small but the medical service is extremely poor.

\begin{tabular}{l|l|c|c|c} 
& $\begin{array}{l}\text { NUMBER } \\
\text { of } \\
\text { PERSONS/Km }\end{array}$ & AREA(Km $\left.{ }^{2}\right) /$ DR. & $\begin{array}{l}\text { NUMBER } \\
\text { of } \\
\text { PERSONS/DR. }\end{array}$ & $\begin{array}{l}\text { RATIO } \\
\text { (JAPAN : 100) }\end{array}$ \\
\hline JAPAN & 280 & 31.5 & 894 & 100 \\
HOKKAIDO & 66 & 78.5 & 1,040 & 106 \\
BEKKAI TOWN & 13.7 & 12.5 & 4,574 & 516 \\
\multicolumn{1}{|l|}{ TABLE 1: THE NUMBER OF PERSONS \& AREA ASSINGNED } \\
TO ONE DOCTOR (1974)
\end{tabular}

Table 2 shows the milking cows for every farmer are increasing in number year by year.

Thus, data presented here will tell you that the working conditions of the farmers are getting worse in spite of the mechanization and modernization of the dairy farming. It should be rather said that the more they purchase machines, the more they have to work!

* Summary of Paper, the 2nd Asian Congress of Rural Medicine, 21-24 April 1975, Tehran Iran

** Sappro Hospital, Hokkaido Association of Medical Service for Workers, Sapporo, Jappan. (Kin-Ikyo Sapporo Hospital) 


\begin{tabular}{c|cccccccc} 
& 68 & 69 & 70 & 71 & 72 & 73 & 74 & 75 \\
\hline $\begin{array}{c}\text { NUMBER } \\
\text { of } \\
\text { COW'S }\end{array}$ & 13.8 & 16.9 & 21.7 & 23.7 & 28.3 & 30.0 & 33.1 & 45.0
\end{tabular}

TABLE 2 : ANNUAL CHANGE OF THE SCALE OF DAIRY FARM - AVERAGE NUMBER OF CATTLE BRED BY EACH FARMER IN BEKKAI AREA

We performed a mass health examination in this area. The purpose of this field work is to clarify the influence of the dairy farm policy of the modernization on the famers' health. From this field work, some significant findings were elicited. First, I will report the problems about the working conditions of the dairy farmers. All members of the families are forced to work for ten to twelve hours a day. The working conditions of the farmers are so severe that it is difficult for them to take rest. Womens' working conditions are especially hard. Most of them continue to work in the pastures until they feel the beginning of labour pains.

Table 3 shows the incidence of "Nofusho" syndrome as compared with that of other farm villages.

\begin{tabular}{|c|c|c|c|}
\hline & \multicolumn{3}{|c|}{ MALE(\%) FEMALE(\%)TOTAL (\%) } \\
\hline TOBETSU TOWN (RICE-GROWING) & 31.2 & 44.3 & 39.3 \\
\hline (DRY FIELD FARMING) & 11.8 & 38.7 & 29.0 \\
\hline BEKKAI TOWN (DAIRY FARMING) & 31.3 & 53.6 & 44.7 \\
\hline
\end{tabular}

TABLE 3 : INCI DENCE OF "NOFUSHO" SYNDROME

"Nofusho" or peasant syndrome is known as a chronic fatigue syndrome of farmers seen in agricultural communities in Japan. This syndrome is caused by agricultural labour and the following symptoms are characteristic, that is, general malaise, drowsy in the daytime, stiffness of the shoulders, low back pain and numbness in the extremities, arthralgia, palpitation, shortness of breath, heartburn and blurred vision.

As you see in the table, the incidence of "Nofusho" in Bekkai dairy farmers is quite high with a frequency of $44.7 \%$. This will indicate the working conditions of the dairy farmers are as equally hard as that of other kind of farming.

Clinical examination are characterized by the high frequency of stomach disorders such as polyps, gastritis or ulcers, essencial hypertension, neuralgia, lowbackpain, and positive tests for urinary protein and sugar.

To know the relation between the scale of dairy operation and the in cidence of the diseases, we devided the dairy farmers into three groups, namely, the big scale breeders who own more than eighty cows, the middle scale breeders ranging from fifty to sixty, the small scale breeders ranging from ten to thirty, respectively. Among these three groups, no significant differences were seen in the actual working hours and also in the incidence of "Nofusho" syndrome. This should suggest that the big scale breeding doesn't necessarily improve the working conditions.

Generally speaking, the dairy farmers in Bekkai area have been troubled with long and hard working conditions and the poor medical service.

From our field work, I would like to conclude that, in the modernization policy of dairy farming, the carefull consideration should be paid on the health management of the farmers. 